\title{
BMJ Open Association of elder abuse, crime victimhood and perceived neighbourhood safety with major depression among older adults in India: a cross-sectional study using data from the LASI baseline survey (2017-2018)
}

T Muhammad (D), Trupti Meher, T V Sekher

To cite: Muhammad T, Meher T, Sekher TV. Association of elder abuse, crime victimhood and perceived neighbourhood safety with major depression among older adults in India: a cross-sectional study using data from the LASI baseline survey (2017-2018). BMJ Open 2021;11:e055625. doi:10.1136/ bmjopen-2021-055625

- Prepublication history for this paper is available online. To view these files, please visit the journal online (http://dx.doi. org/10.1136/bmjopen-2021 055625).

Received 19 July 2021 Accepted 11 November 2021

(D) Check for updates

(c) Author(s) (or their employer(s)) 2021. Re-use permitted under CC BY-NC. No commercial re-use. See rights and permissions. Published by BMJ.

Department of Family and Generations, International Institute for Population Sciences, Mumbai, Maharashtra, India

Correspondence to

T Muhammad;

muhammad.iips@gmail.com

\section{ABSTRACT}

Objective The study aims to explore the associations of elder abuse, crime victimhood and perceived safety with depression among older adults and examine the interactive effects of sex and place of residence in those associations.

Design A cross-sectional study was conducted using a large survey data.

Setting and participants The study used data from the Longitudinal Ageing Study in India wave 1 (2017-2018). The effective sample size was 31464 older adults (aged 60 years or older).

Primary and secondary outcome measures The outcome variable was major depression, calculated using Short Form Composite International Diagnostic Interview. Descriptive statistics along with bivariate and multivariate analyses were performed to fulfil the objectives.

Results $5.22 \%$ of the older adults $(n=1587)$ experienced abuse in the past 1 year. $1.33 \%$ of the older individuals $(n=402)$ were victims of a violent crime, and $14.30 \%$ $(\mathrm{n}=1886)$ perceived an unsafe neighbourhood. Also, $8.67 \%$ of the older adults $(n=2657)$ were suffering from depression. Older adults who were abused had 2.5 odds of suffering from depression (adjusted OR (AOR): 2.47, $\mathrm{Cl}: 1.96$ to 3.10 ) and victims of a violent crime were 84\% more likely to be depressed (AOR: $1.84, \mathrm{Cl}: 1.15$ to 2.95) compared with their counterparts. Besides, older individuals who perceived as living in unsafe neighbourhood were $61 \%$ more likely to be depressed (AOR: 1.61, Cl: 1.34 to 1.93) compared with their counterparts. In the interaction analysis, older women who reported abuse had higher odds of suffering from depression (AOR: 3.27; Cl: 2.34 to 4.57) compared with older men who were not abused. Similar result was found in older adults reporting abuse and residing in rural areas (AOR: 3.01, Cl: 2.22 to 4.07) compared with those urban residents reporting no abuse.

Conclusions Healthcare providers should pay more attention to the mental health implications of elder abuse, crime victimhood and perceived safety to grasp the underlying dynamics of the symptomology of late-life depression.
Strengths and limitations of this study

The study uses a large nationally representative sample of older population.

- Comprehensive information on elder abuse, crime victimhood and perceived neighbourhood safety has been provided in the study.

- The cross-sectional design is a limitation of the study as it is impossible to establish the observed directions of the relationships.

- The self-reported nature of the data can be subjected to reporting or recall biases.

\section{BACKGROUND}

The global population is ageing at a rate that has never been seen before and it is already acknowledged as a worldwide concern. ${ }^{1}$ The process of ageing poses challenges related to depression, which is characterised by persistent feelings of sadness and worthlessness, as well as a loss of interest or pleasure in formerly rewarding or pleasurable pursuits. ${ }^{2}$ According to the WHO, depression has become a prevalent mental disorder affecting over 264 million individuals throughout the world. ${ }^{3}$ In addition, it is presently the third leading cause of global disease burden and according to projections, it will become the leading cause of global burden of disease by 2030. ${ }^{4}$ Depression is especially problematic in older individuals, since it is linked to greater disability, cognitive decline, morbidity and decreased quality of life. ${ }^{5-9}$ A meta-analysis has reported the global prevalence of depressive disorders among the elderly population to be between $4.7 \%$ and $16 \% .{ }^{10}$ Further, according to this study, India has a greater prevalence of geriatric depression than other countries. Another meta-analysis of 51 studies 
in India has found a prevalence estimate of depression to be $34.4 \%$ among older adults aged 60 years and above. ${ }^{11}$ These findings emphasise the fact that depression is a major public health concern among the elderly. Therefore, identifying the determinants of depression among the older population is crucial for developing intervention strategies that might help thousands of older people live with less pain and suffering.

The physiological restrictions, diminished motor strength and comorbid conditions that affect the population at older ages make them a special population group. They also have a limited financial and social support system. These changes in the elderly leave them susceptible to being abused and mistreated by their families and relatives. ${ }^{12}$ The $\mathrm{WHO}^{13}$ has defined elder abuse as 'a single or repeated act, or lack of appropriate action, occurring within any relationship where there is an expectation of trust which causes harm or distress to an older person' ${ }^{13}$ This definition includes several types of abuse, such as physical, sexual, psychological, emotional, financial as well as voluntary negligence. Elder abuse is becoming widely recognised as a public health and human rights concern. ${ }^{14-16}$ In Indian society, elders have always been valued and respected, and families are the primary caretakers of the elderly. However, in the wider context of social and cultural changes, both respect for older persons and the caring traditions of the extended family are waning, making older people expose to abuse, abandonment and loneliness. ${ }^{17-20}$ A study conducted in seven demographically oldest states in India has found the prevalence of elder abuse to be $11 \%$ and is more common in rural India. ${ }^{21}$ However, a report on elder abuse in India has stated that nearly $25 \%$ of older adults have been victims of elder abuse. ${ }^{22}$

Any kind of elder abuse can be regarded as a stressful experience that has a severe impact on the physical as well as mental health of older individual ${ }^{2324}$ with depression and anxiety being the most common psychological outcomes. ${ }^{25} 26$ Further, several studies have found that abused older individuals have higher levels of psychological distress and mental health issues, including depression, than those who have never been mistreated. ${ }^{27-29}$ In addition, repeated abuse or several forms of elder abuse have been identified as risk factors for depression and anxiety among older adults by Fisher and Regan. ${ }^{24}$ Therefore, the current study hypothesises that older individuals who report experiencing elder abuse will have higher odds of depression than those who do not report such experiences.

In addition to physical harm and material loss, being a victim of a criminal act has both immediate and long-term detrimental impacts on mental health. ${ }^{30}{ }^{31} \mathrm{~A}$ limited but growing body of research relates criminal victimisation to a number of undesirable consequences, such as health issues and psychological discomfort. ${ }^{32-34}$ A study by Tan and Haining ${ }^{35}$ has found at least one psychological symptom among $86 \%$ of crime victims as a consequence of their crime experience. ${ }^{35}$ Moreover, depression is one of the most detrimental consequences of victimhood. ${ }^{33}$ However, adolescents and young adults are generally the focus of such research, ${ }^{37}$ with older people being neglected. Nevertheless, there is a dearth of research on the association between crime victimhood and depression in the Indian context. Therefore, this study aimed to assess the relationship between criminal victimhood and depression among older adults.

Perceived safety is an important component of wellbeing while ageing. Therefore, the well-being of older individuals has been linked to their fear of crime, which indicates a lack of subjective safety. ${ }^{38}$ There is a growing body of literature highlighting the negative mental health consequences of fear of crime. ${ }^{39-41}$ Furthermore, fear of crime has been associated with stress, anxiety and depression at older ages. ${ }^{42}{ }^{43}$ However, in a range of mental health conditions linked with fear of crime in older age, depression is particularly important due to its high prevalence in late life. ${ }^{44}$ Further, a number of studies have found that people's physical and social surroundings have a significant impact on their mental health. ${ }^{45-47}$ In particular, research has consistently linked the influence of neighbourhood safety on depressive symptoms. ${ }^{48} 49$ Therefore, this study hypothesises a positive association between feeling unsafe and depression among the older population.

Furthermore, gender and place of residence may have a distinct impact on these relationships. Previous research has shown that older women who have been subjected to recurrent psychological abuse or several kinds of elder abuse are more likely to suffer from depression or psychological distress. ${ }^{24} 2950$ According to Begle et al, ${ }^{26}$ emotional abuse is associated with a greater level of psychological distress among older adults in rural areas. ${ }^{26}$ Moreover, as compared with the older individuals in rural areas, those who live in urban areas are more fearful of crime and have a lower perceived safety. ${ }^{51}$ Besides, a growing body of research suggests that women are more fearful of crime than men. ${ }^{52}$ However, as documented, the association between fear of crime and psychological well-being is stronger in men than in women. ${ }^{53}$

Given the rapid ageing process in developing countries like India, as well as the paucity of studies on psychosocial determinants of healthy ageing, it is crucial to identify the factors affecting older individuals' well-being. Therefore, the aim of this study is to contribute to the literature by evaluating the associations of elder abuse, crime victimhood and perceived safety with depression. The objective of the study is to estimate the prevalence of elder abuse, crime victimhood and perceived safety among older individuals aged 60 years and above in India. Further, the study explores the associations of these three variables with major depression. Additionally, the study examines the interactive effects of gender and place of residence on those associations. The study hypothesised that elder abuse, crime victimhood and perceived safety are positively associated with late-life depression, and gender 
and place of residence have moderating effects on these associations.

\section{METHODS}

\section{Data source}

Data for this study were drawn from the Longitudinal Ageing Study in India (LASI) wave 1, which was conducted during 2017-2018. ${ }^{54}$ The LASI is a full-scale national survey of scientific investigation of the socioeconomic and health status of older population and the consequences of population ageing in India. ${ }^{55}$ It is a nationally representative survey of more than 72000 individuals aged 45 years and above across all states and union territories. As mentioned in previous LASI-based studies, ${ }^{56-58}$ the survey followed a multistage stratified area probability cluster sampling design to arrive at the eventual units of individuals who are aged 45 years and above and their spouses irrespective of age. ${ }^{55}$ The survey in rural areas adopted a three-stage sampling design and in urban areas, a four-stage sampling design. The first stage involved the selection of Primary Sampling Units (PSUs) in each state and union territories, that is, subdistricts (Tehsils/Taluks), and the second stage involved the selection of villages in rural areas and the selection of wards in urban areas in the selected PSUs. In the third stage, households were selected from selected villages in rural areas. However, sampling in urban areas involved an additional stage, that is, one Census Enumeration Block (CEB) was randomly selected in each urban area. In the fourth stage, households were selected from these CEBs.

The survey was designed to select a representative sample at each stage of sample selection. Further, an individual survey schedule was administered to each consenting respondent in the sampled households. The survey also included an individual module on biomarkers and direct health examination of the respondents. As reported in previous analyses of LASI data, the individual response rate of the survey ranged from $96 \%$ in Nagaland to $74 \%$ in Chandigarh. ${ }^{59}$ The detailed methodology, with the complete information on the survey design and data collection, was published in the survey report. ${ }^{55}$ The survey agencies that conducted the field survey for the data collection have collected prior consent from all the respondents. The Indian Council of Medical Research extended the necessary guidelines and ethics approval for undertaking the survey. The present study was conducted on the eligible respondents aged 60 years and above. The effective sample size was 31464 older adults aged 60 years or older.

\section{Variable description}

\section{Outcome variable}

The outcome variable for the study was depression, which was coded as 0 for 'not diagnosed with depression' and 1 for 'diagnosed with depression'. ${ }^{55}$ Major depression among the older adults with symptoms of dysphoria was calculated using the CIDI-SF (Short Form Composite
International Diagnostic Interview) score of 3 or more. Using the survey questions, the people having probable depression were screened. The scale has 10 questions and a positive answer to three or more of those leads to the attribution of the label 'diagnosed with depression'. This scale estimates a probable psychiatric diagnosis of major depression and has been validated in field settings and is widely used in population-based health surveys. Cronbach's alpha indicated that the CIDI-SF has excellent reliability $(\alpha=0.8)$. The lowest 10 th percentile is used as a proxy measure of severe depression among older adults. 855

\section{Explanatory variables}

Elder abuse, crime victimhood and safety perception

1. In the LASI survey, elder abuse was assessed using the question: 'Have you felt that you were ill-treated in the past year?' The response was coded as 'no' and 'yes' ${ }^{60}$

2. To assess the crime victimhood among older individuals, participants were asked: 'In the last 12 months, have you been a victim of a violent crime, such as assault/mugging/threat to life/others?' This item was used dichotomously (no vs yes).

3. The perception of feeling unsafe in the neighbourhood is a subjective measure of neighbourhood safety. To assess the participants' perceived neighbourhood safety, two questions were used. First, they were asked: 'In general, how safe from crime and violence do you feel when you are alone at home?' Further, the participants were asked: 'How safe do you feel when walking down your street/locality alone after dark?' The responses were: (1) completely safe, (2) safe, (3) not very safe and (4) not safe at all. This item was further dichotomised into 'no' representing not feeling unsafe ('completely safe/safe') and 'yes' representing feeling unsafe ('not very safe/not safe at all' for either of the questions).

\section{Individual factors}

1. Age was grouped into 60-69 years, 70-79 years and $80+$ years.

2. Sex was categorised as male and female.

3. Marital status was recoded as 'currently in union' and 'not in union'. The latter included those who were widowed, separated, deserted and never married.

4. Living arrangements were categorised into 'living alone', 'with spouse' and 'other living arrangements'.

5. Educational status was categorised as no/primary, secondary and higher.

6. Working status was categorised as never worked, currently working, not working and retired.

\section{Health factors}

7. Self-rated health was coded as good which includes very good, good and fair; whereas poor includes poor and very poor.

8. Multimorbidity status was categorised as 0 no for 'no multimorbidity', and 1 yes for 'multimorbidity'. 
9. Difficulty in activities of daily living (ADL) was coded as 'no' and 'yes'. ADL is a term used to refer to normal daily self-care activities (such as movement in bed, changing position from sitting to standing, feeding, bathing, dressing, grooming, personal hygiene, etc). The ability or inability to perform ADL is used to measure a person's functional status, especially in the case of people with disabilities and the older adults. ${ }^{61} 62$

10. Difficulty in instrumental ADL (IADL) was coded as 'no' and 'yes'. IADL refers to ADL that are not necessarily related to fundamental functioning of a person, but they let an individual live independently in a community. The set asked was necessary for independent functioning in the community. Respondents were asked if they were having any difficulties that were expected to last more than 3 months, such as preparing a hot meal, shopping for groceries, making a telephone call, taking medications, doing work around the house or garden, managing money (such as paying bills and keeping track of expenses), and getting around or finding an address in unfamiliar places. ${ }^{61} 62$

11. Cognitive impairment was measured through five broad domains (memory, orientation, arithmetic function, executive function and object naming). The overall score ranges between 0 and 43 , and a higher score indicates better cognitive functioning. In our study, the respondents who received assistance during the cognition module were excluded from the analysis. The lowest 10th percentile is used as a proxy measure of poor cognitive functioning.

\section{Household factors}

1. The monthly per capita consumption expenditure (MPCE) quintile was assessed using household consumption data. Sets of 11 and 29 questions on the expenditures on food and non-food items, respectively, were used to canvas the sample households. Food expenditure was collected based on a reference period of 7 days, and non-food expenditure was collected based on reference periods of 30 days and 365 days. Food and non-food expenditures have been standardised to the 30-day reference period. The MPCE is computed and used as the summary measure of consumption. The variable was then divided into five quintiles, that is, from poorest to richest. ${ }^{55}$

2. Religion was coded as Hindu, Muslim and others.

3. Caste was recoded as Scheduled Castes/Scheduled Tribes (SCs/STs), Other Backward Class (OBC) and others. The SCs include 'untouchables', a group of the population that is socially segregated and financially/economically very backward by their low status as per the Hindu caste hierarchy. The SCs and STs are among the most disadvantaged socioeconomic groups in India. The OBC is the group of people who were identified as 'educationally, economically and socially backward'. The 'other' caste category is identified as having higher social status, mostly referring to the higher Hindu castes. ${ }^{63}$

4. Place of residence was categorised as rural and urban.

5. The regions of India were coded as North, Central, East, Northeast, West and South.

\section{Statistical analysis}

In this study, descriptive statistics and bivariate analysis were performed to determine the prevalence of severe depression. $\mathrm{X}^{2}$ test was used to check for intergroup differences in the prevalence of depression among older adults. ${ }^{64}$ Further, binary logistic regression analysis ${ }^{65}$ was used to fulfil the aims and objectives of the study. The results are presented in the form of OR with a $95 \%$ CI.

The equation for logistic regression is as follows:

$$
\ln \left(\frac{P_{i}}{1-P_{i}}\right)=\beta_{0}+\beta_{1} x_{1}+\ldots+\beta_{M} x_{m-1},
$$

where $\beta_{0}, \ldots . ., \beta_{M}$ are regression coefficients indicating the relative effect of a particular explanatory variable on the outcome variable. Further, individual weights were used to make the estimates nationally representative. For the analyses, STATA V.15.1 has been used.

The multivariate analysis provides an unadjusted model and had four models to explain the adjusted estimates. Model 1 provides the adjusted estimates for the control variables. Model 2, model 3 and model 4 provide the interaction effects ${ }^{66}{ }^{67}$ for key variables (elder abuse, crime victimhood and perceived neighbourhood safety) and sex with major depression among older adults. Additionally, an interaction analysis of experiencing violence, being victim of crime and feeling unsafe, and place of residence on major depression was also conducted.

\section{Patient and public involvement}

No patient was involved.

\section{RESULTS}

Background characteristics of the eligible respondents are presented in table 1. Analysis indicated that $5.22 \%$ of the older adults $(n=1587)$ in our sample experienced abuse in the past 1 year. A total of $1.32 \%$ of the respondents $(n=402)$ were victims of crime, whereas $14.30 \%$ of the older participants $(n=2657)$ perceived an unsafe neighbourhood. A total of $11.29 \%$ older participants were from the age group of $80+$ years and $38.37 \%$ older individuals were currently not in a marital union. A majority of the older adults $(73.99 \%)$ were co-residing with their families or others. As far as education is concerned, the majority of the older adults were uneducated or had only primary education $(74.02 \%)$, and only $7.74 \%$ of them had more than 10 years of schooling. A total of $29.97 \%$ of the older adults were working and $26.43 \%$ of them never worked. However, $7.35 \%$ of the older adults were retired from their jobs.

Table 2 presents the proportion of older adults suffering from depression by background characteristics. Overall, $8.67 \%$ of the older adults $(n=2657)$ were suffering from 
Table 1 Socioeconomic profile of the study participants

\begin{tabular}{lrr}
\hline & \multicolumn{2}{c}{ Total (N=31 464) } \\
\cline { 2 - 3 } Background factors & $\mathbf{N}$ & \multicolumn{1}{c}{$\%$} \\
\hline Elder abuse $^{*}$ & & \\
No & 28840 & 94.78 \\
\hline Yes & 1587 & 5.22 \\
\hline
\end{tabular}

Victim of crime*

\begin{tabular}{|crr|}
\hline No & 30025 & 98.68 \\
\hline Yes & 402 & 1.32 \\
\hline Feeling unsafe $^{\star}$ & & \\
\hline No & 26085 & 85.70 \\
\hline Yes & 4354 & 14.30 \\
\hline
\end{tabular}

Age (in years)

$\begin{array}{lrr}60-69 & 18410 & 58.51 \\ 70-79 & 9501 & 30.20 \\ 80+ & 3553 & 11.29\end{array}$

Marital status

\begin{tabular}{|c|c|c|}
\hline Currently in union & 19391 & 61.63 \\
\hline Not in union & 12072 & 38.37 \\
\hline \multicolumn{3}{|l|}{ Living arrangement } \\
\hline Alone & 1788 & 5.68 \\
\hline With spouse & 6396 & 20.33 \\
\hline Others & 23280 & 73.99 \\
\hline \multicolumn{3}{|l|}{ Educational status } \\
\hline No/primary & 23289 & 74.02 \\
\hline Secondary & 5741 & 18.24 \\
\hline Higher & 2434 & 7.74 \\
\hline \multicolumn{3}{|l|}{ Work status } \\
\hline Never worked & 8315 & 26.43 \\
\hline Not working & 11470 & 36.55 \\
\hline Working & 9397 & 29.97 \\
\hline Retired & 2282 & 7.35 \\
\hline \multicolumn{3}{|l|}{ MPCE quintile } \\
\hline Poorest & 6829 & 21.70 \\
\hline Poorer & 6831 & 21.71 \\
\hline Middle & 6590 & 20.95 \\
\hline Richer & 6038 & 19.19 \\
\hline Richest & 5175 & 16.45 \\
\hline \multicolumn{3}{|l|}{ Religion } \\
\hline Hindu & 25871 & 82.20 \\
\hline Muslim & 3548 & 11.30 \\
\hline Others & 2045 & 6.50 \\
\hline \multicolumn{3}{|l|}{ Caste } \\
\hline SC/ST & 8505 & 27.10 \\
\hline OBC & 14231 & 45.20 \\
\hline Others & 8729 & 27.70 \\
\hline
\end{tabular}

Place of residence
Table 1 Continued

\begin{tabular}{lcc}
\hline & \multicolumn{2}{c}{ Total (N=31 464) } \\
\cline { 2 - 3 } Background factors & $\mathbf{N}$ & $\%$ \\
\hline Urban & 22196 & 29.45 \\
Rural & 9268 & 70.55 \\
Region & \\
\hline North & 3960 & 12.59 \\
Central & 6593 & 20.95 \\
East & 7439 & 23.64 \\
Northeast & 935 & 2.97 \\
South & 5401 & 22.68 \\
West & 7136 & 17.17 \\
\hline
\end{tabular}

*Sample size may differ due to missing cases.

MPCE, monthly per capita consumption expenditure; N, absolute numbers; OBC, Other Backward Class; SC, Scheduled Caste; ST, Scheduled Tribe.

depression. As evident from the data, $22.58 \%$ of those who reported elder abuse were suffering from depression (not reported: $7.89 \%$ ); $17.70 \%$ of the older adults who were victims of a violent crime were suffering from depression (against $8.52 \%$ of non-victims). Besides, $13.27 \%$ of those who perceived an unsafe neighbourhood were found to be depressed as against only $7.9 \%$ of those who had perceived a safe neighbourhood.

State-wise prevalence (\%) of elder abuse, crime victimhood and perceived safety among older adults is presented in table 3 . The state of Bihar $(11.65 \%)$ had the highest prevalence of elder abuse among older adults, followed by Karnataka (8.78\%) and West Bengal (7.62\%). On the other hand, the prevalence of crime victimhood was highest in Madhya Pradesh (3.65\%), Delhi (3.33\%) and Arunachal Pradesh (3.26\%). Additionally, 62.49\% of the older participants in Jammu \& Kashmir perceived an unsafe neighbourhood followed by Odisha (45.99\%) and Karnataka $(33.69 \%)$. Notably, older adults living in Lakshadweep and Nagaland had low prevalence of all three indicators used in the study.

Table 4 shows the results obtained from the logistic regression analyses of the socioeconomic and healthrelated variables associated with late-life depression among older Indian adults. Unadjusted estimates reveal that older adults who reported abuse had higher odds of suffering from depression in comparison with those who did not report abuse (unadjusted OR (UOR): 3.13; CI: 2.58 to 3.79 ). Older adults who were victims of violent crimes had higher odds of suffering from depression in reference to their counterparts (UOR: 1.54; CI: 1.05 to 2.26). Further, it was revealed that those who perceived their neighbourhood as unsafe were more likely to be depressed (UOR: 1.65; CI: 1.38 to 1.96) compared with their counterparts living in a safe neighbourhood. In model 1, which is adjusted for all socioeconomic and health-related variables, it was found that older adults who 
Table 2 Bivariate estimates for major depression by background characteristics

\begin{tabular}{|c|c|c|c|}
\hline Variables & $\mathbf{N}$ & $\%$ & $P$ value \\
\hline Elder abuse & & & $<0.001$ \\
\hline No & 2275 & 7.89 & \\
\hline Yes & 358 & 22.58 & \\
\hline Victim of crime & & & $<0.001$ \\
\hline No & 2559 & 8.52 & \\
\hline Yes & 71 & 17.70 & \\
\hline Feeling unsafe & & & $<0.001$ \\
\hline No & 2322 & 7.90 & \\
\hline Yes & 316 & 13.27 & \\
\hline Sex & & & $<0.001$ \\
\hline Male & 1530 & 7.50 & \\
\hline Female & 771 & 9.71 & \\
\hline Age (in years) & 356 & & 0.207 \\
\hline $60-69$ & & 8.41 & \\
\hline $70-79$ & 1085 & 8.42 & \\
\hline $80+$ & 1572 & 10.79 & \\
\hline Marital status & & & $<0.001$ \\
\hline Currently in union & 1472 & 7.77 & \\
\hline Not in union & 1185 & 10.13 & \\
\hline Living arrangement & & & $<0.001$ \\
\hline Alone & 238 & 13.51 & \\
\hline With spouse & 519 & 8.56 & \\
\hline Others & 1900 & 8.32 & \\
\hline Educational status & & & $<0.001$ \\
\hline No/primary & 2171 & 9.55 & \\
\hline Secondary & 353 & 6.39 & \\
\hline Higher & 133 & 5.56 & \\
\hline Working status & & & $<0.001$ \\
\hline Never worked & 615 & 7.59 & \\
\hline Not working & 1133 & 10.33 & \\
\hline Working & 735 & 7.87 & \\
\hline Retired & 174 & 7.74 & \\
\hline $\mathrm{SRH}$ & & & $<0.001$ \\
\hline Good & 1437 & 6.19 & \\
\hline Poor & 1219 & 16.42 & \\
\hline Multimorbidity & & & $<0.001$ \\
\hline No & 1793 & 7.68 & \\
\hline Yes & 861 & 11.80 & \\
\hline ADL difficulty & & & $<0.001$ \\
\hline No & 1580 & 6.69 & \\
\hline Yes & 1076 & 15.34 & \\
\hline IADL difficulty & & & $<0.001$ \\
\hline No & 894 & 5.58 & \\
\hline Yes & 1759 & 12.06 & \\
\hline
\end{tabular}

Continued
Table 2 Continued

\begin{tabular}{lrrr}
\hline Variables & \multicolumn{1}{c}{ N } & \multicolumn{1}{c}{$\%$} & P value \\
\hline Cognitive impairment & & & $<0.001$ \\
\hline No & 1839 & 8.11 & \\
Yes & 409 & 11.46 & \\
\hline MPCE quintile & & & $<0.001$ \\
\hline Poorest & 592 & 8.88 & \\
\hline Poorer & 526 & 7.92 & \\
\hline Middle & 519 & 8.17 & \\
\hline Richer & 519 & 8.74 & \\
\hline Richest & 501 & 9.92 & \\
\hline Religion & & & $<0.001$ \\
\hline Hindu & 2179 & 8.60 & \\
\hline Muslim & 318 & 9.63 & \\
\hline Others & 160 & 7.94 & \\
Caste & & & $<0.001$ \\
\hline SC/ST & 703 & 8.48 & \\
\hline OBC & 1283 & 9.25 & \\
\hline Others & 671 & 7.90 & \\
\hline Place of residence & & & $<0.001$ \\
\hline Urban & 566 & 6.34 & \\
\hline Rural & 2091 & 9.62 & \\
\hline Region & & & $<0.001$ \\
\hline North & 267 & 6.80 & \\
\hline Central & 932 & 14.53 & \\
\hline East & 603 & 8.28 & \\
\hline Northeast & 51 & 5.63 & \\
\hline South & 406 & 5.82 & \\
\hline West & 7.69 & \\
\hline Total & 8.67 & \\
\hline ADL, activits & & \\
\hline
\end{tabular}

$A D L$, activities of daily living; IALD, instrumental activities of daily living; MPCE, monthly per capita consumption expenditure; N, absolute numbers; OBC, Other Backward Class; SC, Scheduled Caste; SRH, self-rated health; ST, Scheduled Tribe.

were abused had 2.5 odds of suffering from depression (adjusted OR (AOR): 2.47, CI: 1.96 to 3.10) compared with those who were not abused. Similarly, crime victims were $84 \%$ more likely to be depressed than non-victims (AOR: 1.84 , CI: 1.15 to 2.95 ). Besides, older individuals with a feeling of an unsafe neighbourhood were $61 \%$ more likely to be depressed in the study (AOR: 1.61, CI: 1.34 to 1.93 ) compared with their safe older counterparts. Models 2, 3 and 4 represent the interaction effects of sex of the older adults in the association of the key variables with depression. Older women who reported abuse had 3.3 odds of suffering from depression (AOR: 3.27; CI: 2.34 to 4.57 ) in reference to older men who were not abused. Similarly, older women who were victims of violent crimes had 2.6 odds of suffering from depression (AOR: 2.62; 
Table 3 State-wise prevalence (\%) of elder abuse, crime victimhood and unsafe neighbourhood among older adults (60+ years) in India, LASI wave 1, 2017-2018

\begin{tabular}{|c|c|c|c|}
\hline & Elder abuse* & Crime victimisation & Unsafe neighbourhood \\
\hline State/UT & $\%$ & $\%$ & $\%$ \\
\hline Jammu \& Kashmir & 1.97 & 0.96 & 62.49 \\
\hline Himachal Pradesh & 1.06 & 0.87 & 2.95 \\
\hline Punjab & 2.14 & 0.90 & 2.29 \\
\hline Chandigarh & 5.55 & 1.34 & 7.86 \\
\hline Uttarakhand & 2.51 & 0.94 & 7.15 \\
\hline Haryana & 3.47 & 0.56 & 5.76 \\
\hline Delhi & 3.48 & 3.33 & 9.26 \\
\hline Rajasthan & 3.28 & 0.89 & 4.87 \\
\hline Uttar Pradesh & 6.47 & 1.96 & 12.67 \\
\hline Bihar & 11.65 & 1.03 & 5.05 \\
\hline Arunachal Pradesh & 4.22 & 3.26 & 8.93 \\
\hline Nagaland & 0.22 & 0.00 & 0.06 \\
\hline Manipur & 1.87 & 0.28 & 10.01 \\
\hline Mizoram & 0.19 & 0.55 & 4.10 \\
\hline Tripura & 1.65 & 0.57 & 0.67 \\
\hline Meghalaya & 0.74 & 0.47 & 30.48 \\
\hline Assam & 2.91 & 0.99 & 9.59 \\
\hline West Bengal & 7.62 & 2.03 & 10.22 \\
\hline Jharkhand & 5.63 & 1.07 & 14.94 \\
\hline Odisha & 2.86 & 0.75 & 45.99 \\
\hline Chhattisgarh & 5.54 & 1.04 & 11.38 \\
\hline Madhya Pradesh & 5.13 & 3.65 & 7.57 \\
\hline Gujarat & 3.04 & 0.50 & 6.63 \\
\hline Daman \& Diu & 3.39 & 0.60 & 2.22 \\
\hline Dadra \& Nagar Haveli & 3.16 & 1.28 & 10.04 \\
\hline Maharashtra & 3.96 & 0.73 & 20.99 \\
\hline Andhra Pradesh & 2.12 & 0.83 & 21.00 \\
\hline Karnataka & 8.78 & 1.74 & 33.69 \\
\hline Goa & 1.54 & 0.5 & 27.79 \\
\hline Lakshadweep & 0.00 & 0.14 & 0.78 \\
\hline Kerala & 3.48 & 1.40 & 15.92 \\
\hline Tamil Nadu & 2.49 & 0.40 & 2.54 \\
\hline Puducherry & 1.73 & 0.73 & 1.99 \\
\hline Andaman \& Nicobar Islands & 1.51 & 2.27 & 18.60 \\
\hline Telangana & 2.24 & 0.66 & 21.85 \\
\hline India & 5.22 & 1.32 & 14.30 \\
\hline
\end{tabular}

${ }^{\star}$ Experienced elder abuse during the last 1 year period.

LASI, Longitudinal Ageing Study in India; UT, union territory.

CI: 1.26 to 5.44) compared with older adults who were non-victims. Additionally, older participants who had a perception of living in an unsafe neighbourhood had 2.2 odds of suffering from late-life depression (AOR: 2.20; CI: 1.68 to 2.88 ) in comparison with their counterparts who perceived a safe neighbourhood.
Table 5 represents the interaction effect of place of residence on the observed associations. It was found that older adults who reported abuse and residing in rural areas were more likely to have depression (AOR: 3.01, CI: 2.22 to 4.07) compared with those reporting no abuse and had an urban residence. Also, those who were victims 
Open access

Table 4 Logistic regression estimates of major depression by socioeconomic characteristics among older adults

\begin{tabular}{|c|c|c|c|c|c|}
\hline & & AOR $(95 \% \mathrm{Cl})$ & AOR (95\% Cl) & AOR (95\% Cl) & AOR (95\% Cl) \\
\hline Variables & Unadjusted OR & Model 1 & Model 2 & Model 3 & Model 4 \\
\hline \multicolumn{6}{|c|}{ Elder abuse } \\
\hline No & 1 & 1 & & 1 & 1 \\
\hline Yes & $\begin{array}{l}3.129^{\star \star \star}(2.582 \text { to } \\
3.793)\end{array}$ & $\begin{array}{l}2.468^{* * *}(1.964 \text { to } \\
3.103)\end{array}$ & & $\begin{array}{l}2.470^{\star * \star}(1.965 \text { to } \\
3.105)\end{array}$ & $\begin{array}{l}2.469^{* \star *}(1.964 \text { to } \\
3.103)\end{array}$ \\
\hline
\end{tabular}

Victim of crime

$\begin{array}{lllll}\text { No } & 1 & 1 & 1 & 1 \\ \text { Yes } & 1.537^{* *}(1.046 \text { to } & 1.842^{* *}(1.151 \text { to } & 1.836^{* *}(1.148 \text { to } & 1.846^{* *}(1.154 \text { to } \\ & 2.258) & 2.948) & 2.936) & 2.953)\end{array}$

Feeling unsafe

\begin{tabular}{|c|c|c|c|c|c|}
\hline No & 1 & 1 & 1 & 1 & \\
\hline Yes & $\begin{array}{l}1.646^{\star \star \star}(1.380 \text { to } \\
1.962)\end{array}$ & $\begin{array}{l}1.611^{\star \star \star}(1.344 \text { to } \\
1.931)\end{array}$ & $\begin{array}{l}1.611^{* \star *} \text { (1.344 to } \\
1.931)\end{array}$ & $\begin{array}{l}1.611^{\star \star \star} \text { (1.345 to } \\
1.931)\end{array}$ & \\
\hline \multicolumn{6}{|l|}{ Sex } \\
\hline Male & & 1 & & & \\
\hline Female & & $\begin{array}{l}1.354^{* * *}(1.112 \text { to } \\
1.649)\end{array}$ & & & \\
\hline \multicolumn{6}{|l|}{ Age (in years) } \\
\hline $60-69$ & & 1 & 1 & 1 & 1 \\
\hline $70-79$ & & $\begin{array}{l}0.765^{\star \star *} \text { (0.643 to } \\
0.911)\end{array}$ & $\begin{array}{l}0.765^{\star \star \star}(0.642 \text { to } \\
0.910)\end{array}$ & $\begin{array}{l}0.765^{\star \star \star}(0.643 \text { to } \\
0.911)\end{array}$ & $\begin{array}{l}0.765^{\star \star \star}(0.643 \text { to } \\
0.911)\end{array}$ \\
\hline $80+$ & & $\begin{array}{l}0.784 \text { ( } 0.573 \text { to } \\
1.073)\end{array}$ & $\begin{array}{l}0.783 \text { (0.572 to } \\
1.072)\end{array}$ & 0.784 (0.573 to 1.073$)$ & $\begin{array}{l}0.784 \text { (0.573 to } \\
1.072)\end{array}$ \\
\hline \multicolumn{6}{|l|}{ Marital status } \\
\hline Currently in union & & 1 & 1 & 1 & 1 \\
\hline Not in union & & $\begin{array}{l}1.145 \text { ( } 0.941 \text { to } \\
1.393)\end{array}$ & $\begin{array}{l}1.145 \text { (0.941 to } \\
1.393)\end{array}$ & 1.145 (0.941 to 1.393$)$ & $\begin{array}{l}1.145 \text { (0.941 to } \\
1.393)\end{array}$ \\
\hline \multicolumn{6}{|l|}{ Living arrangement } \\
\hline Alone & & 1 & 1 & 1 & 1 \\
\hline With spouse & & $\begin{array}{l}0.871 \text { ( } 0.602 \text { to } \\
1.261)\end{array}$ & $\begin{array}{l}0.871 \text { ( } 0.602 \text { to } \\
1.260)\end{array}$ & 0.871 (0.602 to 1.261$)$ & $\begin{array}{l}0.872 \text { (0.602 to } \\
1.261)\end{array}$ \\
\hline Others & & $\begin{array}{l}0.825 \text { ( } 0.601 \text { to } \\
1.134)\end{array}$ & $\begin{array}{l}0.825 \text { (0.601 to } \\
1.134)\end{array}$ & 0.825 (0.601 to 1.134$)$ & $\begin{array}{l}0.825 \text { (0.601 to } \\
1.133)\end{array}$ \\
\hline
\end{tabular}

Educational status

\begin{tabular}{|c|c|c|c|c|}
\hline No/primary & 1 & 1 & 1 & 1 \\
\hline Secondary & $\begin{array}{l}0.868(0.702 \text { to } \\
1.073)\end{array}$ & $\begin{array}{l}0.867 \text { ( } 0.702 \text { to } \\
1.072)\end{array}$ & 0.869 (0.703 to 1.074$)$ & $\begin{array}{l}0.867 \text { ( } 0.701 \text { to } \\
1.072)\end{array}$ \\
\hline Higher & $\begin{array}{l}0.710^{* \star}(0.505 \text { to } \\
0.999)\end{array}$ & $\begin{array}{l}0.709^{\star \star}(0.505 \text { to } \\
0.997)\end{array}$ & $0.711^{* *}(0.505$ to 0.999$)$ & $\begin{array}{l}0.710^{\star *}(0.505 \text { to } \\
0.998)\end{array}$ \\
\hline \multicolumn{5}{|l|}{ Working status } \\
\hline Never worked & 1 & 1 & 1 & 1 \\
\hline Not working & $\begin{array}{l}1.595^{\star \star \star}(1.281 \text { to } \\
1.986)\end{array}$ & $\begin{array}{l}1.597^{\star \star \star} \text { (1.283 to } \\
1.989)\end{array}$ & $\begin{array}{l}1.595^{\star \star \star} \text { (1.281 to } \\
1.986)\end{array}$ & $\begin{array}{l}1.596^{\star \star \star}(1.282 \text { to } \\
1.987)\end{array}$ \\
\hline Working & $\begin{array}{l}1.783^{\star * \star}(1.402 \text { to } \\
2.267)\end{array}$ & $\begin{array}{l}1.785^{\star * *} \text { (1.403 to } \\
2.271 \text { ) }\end{array}$ & $\begin{array}{l}1.783^{\star * \star} \text { (1.403 to } \\
2.267 \text { ) }\end{array}$ & $\begin{array}{l}1.782^{\star \star \star}(1.401 \text { to } \\
2.267)\end{array}$ \\
\hline Retired & $\begin{array}{l}1.904^{\star \star \star}(1.314 \text { to } \\
2.759)\end{array}$ & $\begin{array}{l}1.910^{\star \star \star}(1.318 \text { to } \\
2.770)\end{array}$ & $\begin{array}{l}1.903^{\star \star \star}(1.313 \text { to } \\
2.758)\end{array}$ & $\begin{array}{l}1.903^{\star \star \star}(1.313 \text { to } \\
2.758)\end{array}$ \\
\hline \multicolumn{5}{|l|}{ SRH } \\
\hline Good & 1 & 1 & 1 & 1 \\
\hline
\end{tabular}

Continued 
Table 4 Continued

\begin{tabular}{|c|c|c|c|c|c|}
\hline & & AOR (95\% Cl) & AOR (95\% Cl) & AOR (95\% Cl) & AOR (95\% Cl) \\
\hline Variables & Unadjusted OR & Model 1 & Model 2 & Model 3 & Model 4 \\
\hline Poor & & $\begin{array}{l}2.438^{* * *}(2.065 \text { to } \\
2.877)\end{array}$ & $\begin{array}{l}2.437^{\star \star \star} \text { (2.065 to } \\
2.876)\end{array}$ & $\begin{array}{l}2.437^{\star \star \star} \text { (2.065 to } \\
2.877)\end{array}$ & $\begin{array}{l}2.440^{* * *}(2.069 \text { to } \\
2.879)\end{array}$ \\
\hline \multicolumn{6}{|c|}{ Multimorbidity } \\
\hline No & & 1 & 1 & 1 & 1 \\
\hline \multicolumn{6}{|c|}{ ADL difficulty } \\
\hline No & & 1 & 1 & 1 & 1 \\
\hline Yes & & $\begin{array}{l}1.717^{\star \star \star} \text { (1.394 to } \\
2.116)\end{array}$ & $\begin{array}{l}1.717^{\star \star \star} \text { (1.393 to } \\
2.116)\end{array}$ & $\begin{array}{l}1.718^{\star \star \star} \text { (1.394 to } \\
2.116)\end{array}$ & $\begin{array}{l}1.717^{\star \star \star} \text { (1.394 to } \\
2.115)\end{array}$ \\
\hline
\end{tabular}

IADL difficulty

\begin{tabular}{|c|c|c|c|c|}
\hline No & 1 & 1 & 1 & 1 \\
\hline Yes & $\begin{array}{l}1.528^{\star \star \star}(1.270 \text { to } \\
1.839)\end{array}$ & $\begin{array}{l}1.529^{\star \star \star} \text { (1.270 to } \\
1.840)\end{array}$ & $\begin{array}{l}1.528^{\star \star \star} \text { (1.270 to } \\
1.839)\end{array}$ & $\begin{array}{l}1.528^{\star \star \star}(1.270 \text { to } \\
1.839)\end{array}$ \\
\hline No & 1 & 1 & 1 & 1 \\
\hline Yes & $\begin{array}{l}1.019(0.834 \text { to } \\
1.246)\end{array}$ & $\begin{array}{l}1.020(0.834 \text { to } \\
1.247)\end{array}$ & $1.019(0.834$ to 1.246$)$ & $\begin{array}{l}1.018(0.832 \text { to } \\
1.246)\end{array}$ \\
\hline Poorest & 1 & 1 & 1 & 1 \\
\hline Poorer & $\begin{array}{l}0.912 \text { ( } 0.737 \text { to } \\
1.127)\end{array}$ & $\begin{array}{l}0.912 \text { (0.738 to } \\
1.127)\end{array}$ & 0.911 (0.737 to 1.127$)$ & $\begin{array}{l}0.912 \text { ( } 0.737 \text { to } \\
1.127)\end{array}$ \\
\hline Middle & $\begin{array}{l}1.008(0.775 \text { to } \\
1.311)\end{array}$ & $\begin{array}{l}1.007 \text { (0.774 to } \\
1.310)\end{array}$ & $1.008(0.775$ to 1.311$)$ & $\begin{array}{l}1.008(0.775 \text { to } \\
1.311)\end{array}$ \\
\hline \multicolumn{5}{|l|}{ Religion } \\
\hline Hindu & 1 & 1 & 1 & 1 \\
\hline Muslim & $\begin{array}{l}0.898 \text { ( } 0.709 \text { to } \\
1.138)\end{array}$ & $\begin{array}{l}0.898 \text { (0.709 to } \\
1.139)\end{array}$ & 0.898 (0.709 to 1.139$)$ & $\begin{array}{l}0.897 \text { ( } 0.708 \text { to } \\
1.138)\end{array}$ \\
\hline Others & $\begin{array}{l}1.283^{*}(0.964 \text { to } \\
1.709)\end{array}$ & $\begin{array}{l}1.284^{*}(0.964 \text { to } \\
1.709)\end{array}$ & $1.284^{*}(0.965$ to 1.709$)$ & $\begin{array}{l}1.284^{*}(0.964 \text { to } \\
1.709)\end{array}$ \\
\hline \multicolumn{5}{|l|}{ Caste } \\
\hline $\mathrm{SC} / \mathrm{ST}$ & 1 & 1 & 1 & 1 \\
\hline OBC & $\begin{array}{l}1.428^{\star \star \star} \text { (1.173 to } \\
1.738)\end{array}$ & $\begin{array}{l}1.428^{\star \star \star}(1.174 \text { to } \\
1.739)\end{array}$ & $\begin{array}{l}1.428^{\star \star \star} \text { (1.173 to } \\
1.738)\end{array}$ & $\begin{array}{l}1.428^{\star \star \star}(1.173 \text { to } \\
1.738)\end{array}$ \\
\hline \multicolumn{5}{|l|}{ Region } \\
\hline \multicolumn{5}{|l|}{ North } \\
\hline Central & $\begin{array}{l}2.198^{\star \star \star} \text { (1.732 to } \\
2.788)\end{array}$ & $\begin{array}{l}2.197^{\star \star \star} \text { (1.732 to } \\
2.788)\end{array}$ & $\begin{array}{l}2.197^{\star \star \star} \text { (1.732 to } \\
2.787)\end{array}$ & $\begin{array}{l}2.198^{\star * \star}(1.732 \text { to } \\
2.788)\end{array}$ \\
\hline
\end{tabular}


Table 4 Continued

\begin{tabular}{|c|c|c|c|c|c|}
\hline & & AOR (95\% Cl) & AOR (95\% Cl) & AOR $(95 \% \mathrm{Cl})$ & AOR (95\% Cl) \\
\hline Variables & Unadjusted OR & Model 1 & Model 2 & Model 3 & Model 4 \\
\hline East & & $\begin{array}{l}0.976 \text { (0.783 to } \\
1.217)\end{array}$ & $\begin{array}{l}0.976 \text { (0.783 to } \\
1.217)\end{array}$ & 0.976 (0.783 to 1.217$)$ & $\begin{array}{l}0.976 \text { (0.782 to } \\
1.217)\end{array}$ \\
\hline Northeast & & $\begin{array}{l}0.778 \text { (0.550 to } \\
1.101)\end{array}$ & $\begin{array}{l}0.778(0.550 \text { to } \\
1.100)\end{array}$ & 0.778 (0.550 to 1.101$)$ & $\begin{array}{l}0.778 \text { (0.550 to } \\
1.101)\end{array}$ \\
\hline South & & $\begin{array}{l}0.520^{\star \star \star}(0.395 \text { to } \\
0.683)\end{array}$ & $\begin{array}{l}0.520^{\star \star \star}(0.396 \text { to } \\
0.683)\end{array}$ & $\begin{array}{l}0.520^{\star \star \star}(0.396 \text { to } \\
0.683)\end{array}$ & $\begin{array}{l}0.519^{\star \star \star}(0.395 \text { to } \\
0.683)\end{array}$ \\
\hline West & & $\begin{array}{l}0.874 \text { ( } 0.669 \text { to } \\
1.143 \text { ) }\end{array}$ & $\begin{array}{l}0.874 \text { ( } 0.669 \text { to } \\
1.143)\end{array}$ & 0.875 (0.669 to 1.143 ) & $\begin{array}{l}0.873 \text { ( } 0.667 \text { to } \\
1.143 \text { ) }\end{array}$ \\
\hline
\end{tabular}

Elder abuse \# sex

\begin{tabular}{|c|c|c|}
\hline No \# male & 1 & \\
\hline No \# female & $\begin{array}{l}1.364^{\star \star \star}(1.109 \text { to } \\
1.677)\end{array}$ & \\
\hline Yes \# male & $\begin{array}{l}2.566^{\star \star \star}(1.841 \text { to } \\
3.577)\end{array}$ & \\
\hline Yes \# female & $\begin{array}{l}3.271^{\star \star \star}(2.342 \text { to } \\
4.567)\end{array}$ & \\
\hline \multicolumn{3}{|l|}{ Victim \# sex } \\
\hline No \# male & & 1 \\
\hline No \# female & & $\begin{array}{l}1.351^{\star \star \star}(1.107 \text { to } \\
1.648)\end{array}$ \\
\hline Yes \# male & & $1.759^{*}(0.949$ to 3.261$)$ \\
\hline Yes \# female & & $\begin{array}{l}2.621^{\star * \star}(1.263 \text { to } \\
5.437)\end{array}$ \\
\hline
\end{tabular}

Feeling unsafe \# sex

\begin{tabular}{|c|c|c|c|}
\hline No \# male & & & 1 \\
\hline No \# female & & & $\begin{array}{l}1.341^{\star \star \star} \text { (1.087 to } \\
1.655)\end{array}$ \\
\hline Yes \# male & & & $\begin{array}{l}1.562^{* \star *}(1.163 \text { to } \\
2.097)\end{array}$ \\
\hline Yes \# female & & & $\begin{array}{l}2.202^{* * \star}(1.683 \text { to } \\
2.882)\end{array}$ \\
\hline Pseudo $R^{2}$ & 0.0225 & 0.1141 & 0.1141 \\
\hline
\end{tabular}

${ }^{*} \mathrm{P}<0.05,{ }^{* *} \mathrm{p}<0.01,{ }^{* * *} \mathrm{p}<0.001$.

Model 1 is adjusted for sociodemographic factors such as age, education, marital status, living arrangement and working status, health variables such as SRH, multimorbidity, ADL/IADL difficulties and cognitive impairment along with household factors of MPCE quintile, religion, caste and place of residence; Models 2, 3 and 4 are interaction models, adjusted for all covariates.

ADL, activities of daily living; AOR, adjusted OR; IADL, instrumental activities of daily living; MPCE, monthly per capita consumption expenditure; OBC, Other Backward Class; SC, Scheduled Caste; SRH, self-rated health; ST, Scheduled Tribe.

of violent crimes and residing in rural areas had higher chances of suffering from depression (AOR: 2.27, CI: 1.25 to 4.14 ) compared with non-victim urban residents. Respondents who perceived their neighbourhood as unsafe and had a rural residence were almost two (AOR: 1.99, CI: 1.53 to 2.60 ) times more likely to suffer from depression in comparison with the urban resident participants who perceived a safe neighbourhood.

\section{DISCUSSION}

In the present study, a substantial proportion of the older population (aged 60 years and above) was found to be suffering from major depression $(8.67 \%)$. A communitybased study from the northern part of India has also found that $6.8 \%$ of the older population was severely depressed. ${ }^{68}$ However, the reported prevalence is much lower than the pooled prevalence reported in the reviews of previous studies in India. ${ }^{10} 11$ The differences in the results may be explained by screening tools and other methodological or sampling differences. Further, 5.22\% of the respondents had experienced elder abuse in the last 1 year and about $14.30 \%$ had reported as feeling unsafe while being alone at home or in the neighbourhood. However, the overall prevalence of elder abuse is 
Table 5 Interaction estimates of experiencing violence, being victim of crime and feeling unsafe, and place of residence of older adults on major depression

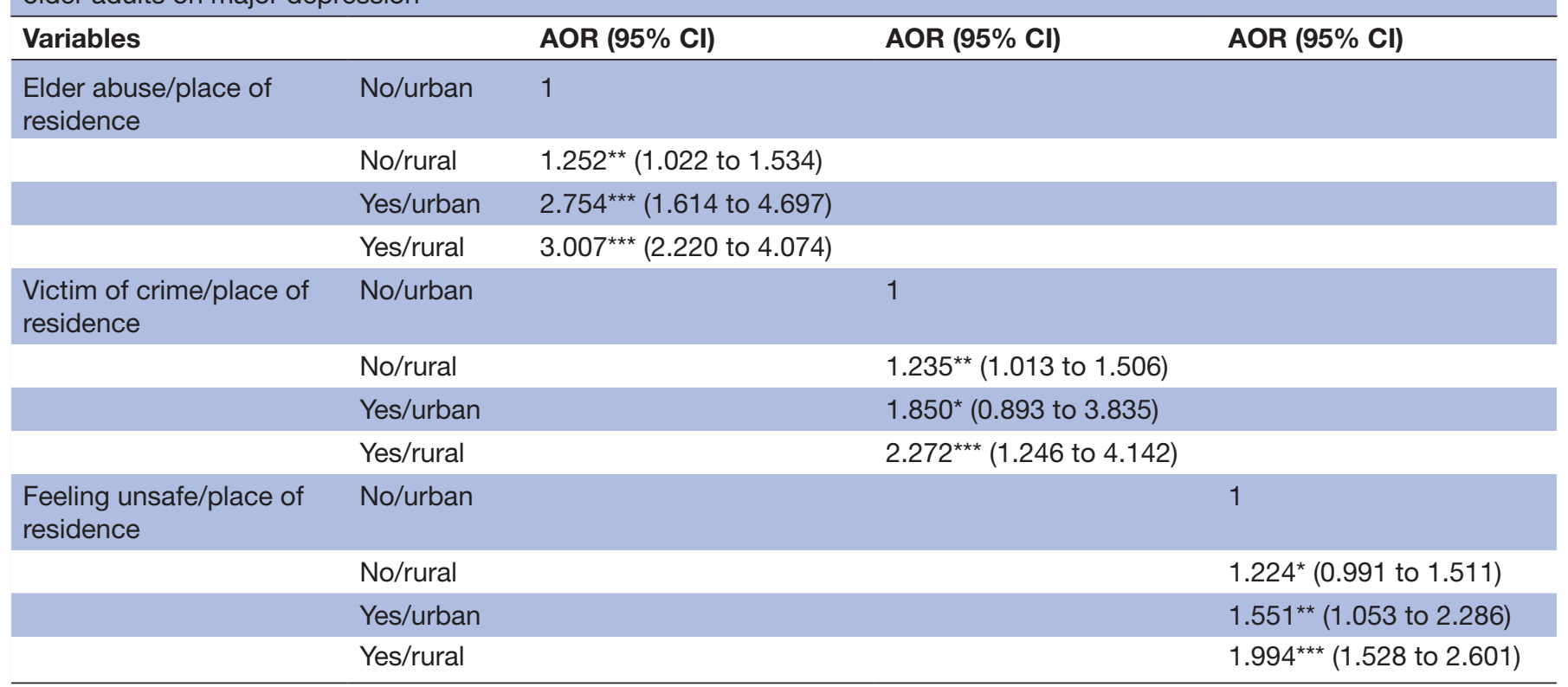

${ }^{*} \mathrm{P}<0.05,{ }^{* *} \mathrm{p}<0.01,{ }^{* *} \mathrm{p}<0.001$.

OR adjusted for sociodemographic factors such as age, education, marital status, living arrangement and working status, health factors such as $\mathrm{SRH}$, multimorbidity, ADL/IADL difficulty and cognitive impairment along with household factors of MPCE quintile, religion, caste and place of residence.

ADL, activities of daily living; AOR, adjusted OR; IADL, instrumental activities of daily living; MPCE, monthly per capita consumption expenditure; $\mathrm{SRH}$, self-rated health.

lower than previously reported in India. ${ }^{2169}$ One probable explanation for under-reporting of elder abuse could be that elder abuse is seen in contrast with Indian cultural values, and as a result, older individuals who have been abused may be ashamed or afraid of stigmatisation, and hence may not reveal this information. ${ }^{70}$ In most cases, the caregivers are the primary abusers and it worsens the victims' helplessness and makes them reluctant or afraid to report such incidents. Our results also indicated a large variation in the prevalence of elder abuse, crime victimhood and perceived neighbourhood safety among the states of India.

After adjusting for confounding variables, the regression analysis revealed that gender, work status, place of residence, self-rated health condition, presence of multimorbidity, functional disabilities such as ADL and IADL difficulties, elder abuse, crime victimhood and perceived neighbourhood safety were factors associated with depression in the older population in India, among which elder abuse had the greatest odds (AOR=2.468). Furthermore, the prevalence of depression was much higher among older individuals who had been victims of elder abuse $(22.58 \%)$ or any crime $(17.70 \%)$ than among those who had never been victims of these situations. In addition, the older adults who reported feeling unsafe had a higher prevalence of depression $(13.27 \%)$ than their counterparts.

The findings of this study suggest that elder abuse has a significant and positive association with depression, since older individuals who had been abused or ill-treated were twice as likely to be depressed as those who had no such experience. This finding supports the first hypothesis outlined in the study. The result is also in line with the findings of previous research, which has identified depression as one of the most serious consequences of elder abuse. ${ }^{24} 297172$ In general, Indian parents invest in their children until adulthood and always expect to be looked after and cared for as they grow older. However, if this investment is not repaid, they are likely to experience feelings of unfairness, which can lead to psychological distress. ${ }^{29}$ Moreover, ill-treatment may deprive a person of much-needed affection, care and emotional support, leaving them despondent and vulnerable to depression. Abuse is believed to be more emotional and less physical in older individuals. ${ }^{73}$ Further, according to Knight and Hester, ${ }^{75}$ emotional or psychological abuse has a more detrimental impact on victims than physical violence and it has a strong link with the increased rate of depression and anxiety in the older population. ${ }^{75}$ Nevertheless, a recent study in Nepal has reported that neglect and economical abuse significantly increase the risk of geriatric depression. ${ }^{76}$ In concordance with earlier research, ${ }^{24}$ the current study has also found significantly increased odds of depression in women who are victims of abuse. Further, in this study, a significant association of elder abuse and place of residence on geriatric depression has been observed in the regression model with interaction analysis.

In accordance with the findings of previous research, ${ }^{313377}$ the current study confirms that experience 
of criminal victimhood is significantly associated with an increased risk of depression. A previous experience of being unable to avert the crime may elicit sentiments of poor self-efficacy and helplessness and such feelings are a major source of depression. ${ }^{31}$ Moreover, fear of crime can also lead to mistrust of others, making it harder to form social relationships ${ }^{39}$ and eventually lead to loneliness and depression. ${ }^{43}$ Therefore, not only the victim's assessments of the original events but fear of similar incidents also affect their psychological well-being. Further, according to the interaction analysis, older individuals who had been victims of crime and living in rural areas were found to be at higher odds of having depression. This result is inconsistent with previous research. ${ }^{77}$ One potential explanation is that in rural regions, there is a lack of law enforcement infrastructure, ${ }^{78}$ which increases the feeling of dread after becoming a victim of crime. In addition, older women who had experienced criminal victimhood were more likely to suffer from depression. This may be attributed to the fact that women have a higher fear of crime than men. ${ }^{53}$ Regarding the pathways of fear of crime leading to mental illnesses, evidence suggests that older individuals who are afraid of crime limit their social activities and use of services, increasing loneliness and contributing to depression. ${ }^{79}$

The present study also investigated the association between perceived neighbourhood safety and depression among older adults and as hypothesised, a positive association was found between feeling unsafe and latelife depression. This association remained significant even after controlling for other socioeconomic factors. The result is consistent with previous studies. ${ }^{48}{ }^{80}$ Stafford $e t a l,{ }^{39}$ in their study on association between fear of crime and mental health and physical functioning, found that individuals reporting high level of fear were $50 \%$ more likely to show symptoms of mental disorder and $90 \%$ more likely to show symptoms of depression than those who reported low levels of fear. ${ }^{39}$ Older individuals are particularly fearful of being attacked, robbed or burgled ${ }^{81}$ and the fear of crime usually affects their mental well-being. ${ }^{41}$ In addition, another study found that an overall neighbourhood safety is most important for mental health among older adults. ${ }^{82}$ However, unexpectedly, our study found that the association between perceived neighbourhood safety and depression is significantly stronger among older individuals living in rural areas. This finding highlights the need for further research in this aspect. The interaction analysis in the study also documented that the magnitude of the association between feeling unsafe and depression was greater in women than in men. This is inconsistent with the finding of a recent study that suggests a stronger negative effect of fear of crime on the psychological wellbeing of men than women. ${ }^{53}$ One possible explanation is that men are more likely than women to under-report their real fear of crime, owing to strong societal gender norms and the expectation of men to demonstrate masculinity. ${ }^{83}$
Our study suffers from several limitations, which should be considered while interpreting the results. The crosssectional nature of the study does not allow establishing any causal relationship. The self-reported nature of the data, including the questions on elder abuse, crime victimhood and perceived neighbourhood safety, can be subjected to reporting or recall biases. Further, because of social and cultural stigma, elder abuse and crime victimhood might be under-reported. Depressive symptoms may also affect perception in older adults. In addition, older adults suffering from depression may be more likely to recall past traumatic incidents than those who were in good mental condition at the time of the survey. The data were obtained from a questionnaire survey performed through face-to-face interviews, which could lead to asking bias. Nevertheless, one of the major strengths of this study is the wider relevance of its results, since it is based on data from a large-scale, nationally representative survey in India.

\section{CONCLUSIONS}

This study fills an important gap in the research on the possible association of elder abuse, crime victimhood, perceived safety and depression among older adults in India. It confirms the association of elder abuse and geriatric depression, paving the way for elder abuse to be recognised as a serious health and human rights issue that can no longer be overlooked. There is a need to develop effective intervention strategies for addressing both elder abuse and depression. Healthcare providers should pay more attention to the health implications of elder abuse, particularly the negative psychological consequences. Further, since the study has established a positive association between crime victimhood and depression in late life, it is also important to investigate the history of the crime in order to grasp the underlying dynamics of the symptomology of depression. The study also highlights the importance of perceived neighbourhood safety for the mental well-being of older adults. Therefore, improving neighbourhood environment (eg, lighting, maintenance) and providing supportive services (eg, transportation, police) would contribute to enhance the perceived neighbourhood safety. Moreover, future research could investigate the influences of elder abuse, criminal victimhood and perceived safety on the mental status of older population with longitudinal design using the follow-up data.

Contributors TMuhammad and TVS conceived and designed the research paper TMuhammad analysed the data. TVS and TMeher contributed agents/materials/ analysis tools. TMuhammad and TMeher wrote the manuscript. TMuhammad, TMeher and TVS refined the manuscript. TMuhammad is responsible for the overall content and acts as the guarantor.

Funding The authors have not declared a specific grant for this research from any funding agency in the public, commercial or not-for-profit sectors.

Competing interests None declared.

Patient and public involvement Patients and/or the public were not involved in the design, or conduct, or reporting, or dissemination plans of this research. 
Patient consent for publication Not required.

Ethics approval The data are freely available in the public domain and survey agencies that conducted the field survey for the data collection have collected prior consent from the respondents. The Indian Council of Medical Research (ICMR) and all partner institutions extended the necessary guidance and ethical approval for conducting the LASI survey. All methods were carried out in accordance with relevant guidelines and regulations by the ICMR.

Provenance and peer review Not commissioned; externally peer reviewed.

Data availability statement Data are available in a public, open access repository. Data are available in a public, open access repository. The data are freely available in the public domain and survey agencies that conducted the field survey for the data collection have collected prior consent from the respondents. The Indian Council of Medical Research (ICMR) and all partner institutions extended the necessary guidance and ethical approval for conducting the LASI survey. All methods were carried out in accordance with relevant guidelines and regulations by the Indian Council of Medical Research (ICMR).

Open access This is an open access article distributed in accordance with the Creative Commons Attribution Non Commercial (CC BY-NC 4.0) license, which permits others to distribute, remix, adapt, build upon this work non-commercially, and license their derivative works on different terms, provided the original work is properly cited, appropriate credit is given, any changes made indicated, and the use is non-commercial. See: http://creativecommons.org/licenses/by-nc/4.0/.

ORCID iD

T Muhammad http://orcid.org/0000-0003-1486-7038

\section{REFERENCES}

1 WHO. Global health and ageing. World Health Organization, 2011.

2 WHO. Depression and other common mental disorders: global health estimates. World Health Organization, 2017.

3 World Health Organization. Depression [Internet], 2020. Available: https://www.who.int/news-room/fact-sheets/detail/depression [Accessed 05 Jul 2021].

4 Institute for Health Metrics and Evaluation. Findings from the global burden of disease study 2017 | Institute for health metrics and evaluation. Inst Heal Metrics Eval Lancet 2018;27.

5 Lenze EJ, Rogers JC, Martire LM, et al. The association of latelife depression and anxiety with physical disability: a review of the literature and prospectus for future research. Am J Geriatr Psychiatry 2001;9:113-35.

6 Ávila-Funes JA, Melano-Carranza E, Payette H, et al. Síntomas depresivos como factor de riesgo de dependencia en adultos mayores. Salud pública Méx 2007;49:367-75.

7 Katon WJ. Epidemiology and treatment of depression in patients with chronic medical illness. Dialogues Clin Neurosci 2011;13:7-24.

8 Muhammad T, Meher T. Association of late-life depression with cognitive impairment: evidence from a cross-sectional study among older adults in India. BMC Geriatr 2021;21:1-13.

9 Akosile CO, Mgbeojedo UG, Maruf FA, et al. Depression, functional disability and quality of life among Nigerian older adults: prevalences and relationships. Arch Gerontol Geriatr 2018;74:39-43.

10 Barua A, Ghosh MK, Kar N, et al. Prevalence of depressive disorders in the elderly. Ann Saudi Med 2011;31:620-4.

11 Pilania M, Yadav V, Bairwa M, et al. Prevalence of depression among the elderly (60years and above) population in India, 1997-2016: a systematic review and meta-analysis. BMC Public Health 2019;19:1-18.

12 Mawar S, Koul P, Das S, et al. Association of physical problems and depression with elder abuse in an urban community of North India. Indian J Community Med 2018;43:165-9.

13 WHO. Missing voices : views of older persons on elder abuse. Geneva 27, Switzerland: WHO, 2002.

14 Dong XQ. Elder abuse: systematic review and implications for practice. J Am Geriatr Soc 2015;63:1214-38.

15 Pillemer K, Burnes D, Riffin C, et al. Elder abuse: global situation, risk factors, and prevention strategies. Gerontologist 2016;56 Suppl 2:S194-205.

16 Sekher T. Elder abuse in India: emerging evidences. Geogr you 2019;19:60-8.

17 Patel V, Prince M. Ageing and mental health in a developing country: who cares? Qualitative studies from Goa, India. Psychol Med 2001;31:29-38

18 Srivastava S, Bhatia MS, Rajoura OP. Elder neglect in changing Indian scenario. Delhi Psychiatry J 2013;16:273-6.
19 Sebastian D, Sekher TV. Abuse and neglect of elderly in Indian families: findings of elder abuse screening test in Kerala. J Indian Acad Geriatr 2010;2:54-60.

20 Sebastian D, Sekher TV. Are elderly people safe in their own households? New evidence from seven states of India. In: Abuse and neglect of the elderly in India, 2018: 157-74.

21 Skirbekk V, James KS. Abuse against elderly in India--the role of education. BMC Public Health 2014;14:336.

22 Help Age India. Elder abuse in India 2018 -Changing Cultural Ethos \& Impact of Technology. New Delhi, India, 2018.

23 Dong X. Medical implications of elder abuse and neglect. Clin Geriatr Med 2005;21:293-313.

24 Fisher BS, Regan SL. The extent and frequency of abuse in the lives of older women and their relationship with health outcomes. Gerontologist 2006;46:200-9.

25 Dyer CB, Pavlik VN, Murphy KP, et al. The high prevalence of depression and dementia in elder abuse or neglect. J Am Geriatr Soc 2000;48:205-8.

26 Begle AM, Strachan M, Cisler JM, et al. Elder mistreatment and emotional symptoms among older adults in a largely rural population: the South Carolina elder mistreatment study. J Interpers Violence 2011;26:2321-32.

27 Luo Y, Waite LJ. Mistreatment and psychological well-being among older adults: exploring the role of psychosocial resources and deficits. J Gerontol B Psychol Sci Soc Sci 2011;66:217-29.

28 Dong XQ, Simon MA, Beck TT, et al. Elder abuse and mortality: the role of psychological and social wellbeing. Gerontology 2011;57:549-58.

29 Evandrou M, Falkingham JC, Qin M, et al. Elder abuse as a risk factor for psychological distress among older adults in India: a crosssectional study. BMJ Open 2017;7:e017152.

30 Stickley A, Koyanagi A, Roberts B, et al. Criminal victimisation and health: examining the relation in nine countries of the former Soviet Union. Soc Sci Med 2013;91:76-83.

31 Hochstetler A, DeLisi M, Jones-Johnson G. The criminal Victimization-Depression sequela: examining the effects of violent victimization on depression with a longitudinal propensity score design. Crime Delinq 2014;60:785-806.

32 Britt CL. Health consequences of criminal victimization. Int Rev Vict 2001;8:63-73.

33 Reisig MD, Holtfreter K, Turanovic JJ. Criminal victimization, depressive symptoms, and behavioral avoidance coping in late adulthood: the conditioning role of strong familial ties. J Adult Dev 2018;25:13-24.

34 Turanovic JJ, Pratt TC. Longitudinal effects of violent victimization during adolescence on adverse outcomes in adulthood: a focus on prosocial attachments. J Pediatr 2015;166:1062-9.

35 Tan S-Y, Haining R. Crime victimization and the implications for individual health and wellbeing: a Sheffield case study. Soc Sci Med 2016;167:128-39.

36 Park G-R, Kim S, Kim N. The association between crime victimization and depressive symptoms among homeless people in Korea: a gender stratified analysis. J Soc Distress Homelessness 2021;21:1-7.

37 Walsh K, Danielson CK, McCauley J, et al. Longitudinal trajectories of posttraumatic stress disorder symptoms and binge drinking among adolescent girls: the role of sexual victimization. $J$ Adolesc Health 2012:50:54-9.

38 Greve W, Leipold B, Kappes C. Fear of crime in old age: a sample case of resilience? J Gerontol B Psychol Sci Soc Sci 2018;73:1224-32.

39 Stafford M, Chandola T, Marmot M. Association between fear of crime and mental health and physical functioning. Am J Public Health 2007;97:2076-81.

40 Pearson AL, Breetzke GD. The association between the fear of crime, and mental and physical wellbeing in New Zealand. Soc Indic Res 2014;119:281-94.

41 Collins RE, Marrone DF. Scared sick: relating fear of crime to mental health in older adults. SAGE Open 2015;5.

42 Beaulieu M, Leclerc N, Dubé M. Chapter 8 fear of crime among the elderly. J Gerontol Soc Work 2004;40:121-38.

43 Golovchanova N, Boersma K, Andershed H, et al. Affective fear of crime and its association with depressive feelings and life satisfaction in advanced age: cognitive emotion regulation as a moderator? Int J Environ Res Public Health 2021;18:4727.

44 Blazer DG. Depression in late life: review and commentary. Focus 2009;7:118-36.

45 Truong KD, Ma S. A systematic review of relations between neighborhoods and mental health. J Ment Health Policy Econ 2006;9:137-54

46 Yen IH, Michael YL, Perdue L. Neighborhood environment in studies of health of older adults. Am J Prev Med 2009;37:455-63. 
47 Berkman LF, Sekher TV, Capistrant B. Social Networks, Family, and Care Giving Among Older Adults in India. In: Aging in Asia: findings from new and emerging data initiatives, 2012: 1-21.

48 Wilson-Genderson M, Pruchno R. Effects of neighborhood violence and perceptions of neighborhood safety on depressive symptoms of older adults. Soc Sci Med 2013;85:43-9.

49 Gonyea JG, Curley A, Melekis K, et al. Perceptions of neighborhood safety and depressive symptoms among older minority urban subsidized housing residents: the mediating effect of sense of community belonging. Aging Ment Health 2018;22:1564-9.

50 Vilar-Compte M, Giraldo-Rodríguez L, Ochoa-Laginas A, et al. Association between depression and elder abuse and the mediation of social support: a cross-sectional study of elder females in Mexico City. J Aging Health 2018;30:559-83.

51 Rohner R, Hope S, Obex T. The fear of crime among older adults in Austria. An urban-rural comparison of the influence of social disorder on the fear of crime in public spaces. J Police Sci Pract 2020;10:54-64.

52 Collins RE. Addressing the inconsistencies in fear of crime research: a meta-analytic review. J Crim Justice 2016;47:21-31.

53 JML L, Ang S, Chan A. Fear of crime is associated with loneliness among older adults in Singapore: gender and ethnic differences. Heal Soc Care Community 2019;2020:1-10.

54 International Institute for Population Sciences (IIPS). LASI - Data [Internet]. Longitudinal Ageing Study in India (LASI) - Datasets, 2020 Available: https://www.iipsindia.ac.in/content/LASI-data [Accessed 24 Nov 2021].

55 International Institute for Population Sciences (IIPS), NPHCE, MoHFW, Harvard T. H. Chan School of Public Health (HSPH), The University of Southern California (USC). Longitudinal ageing study in India (LASI) wave 1. India report. Mumbai, India, 2020.

56 Muhammad T, Maurya P, Sharma P. Prevalence and correlates of bone and joint diseases and its association with falls among older adults in India: evidence from LASI, 2017-18. Geriatr Nurs 2021;42:1143-50.

57 Chauhan S. Do Functional Limitations Predict Life Satisfaction Among Elderly in India : A Study Based On LASI Survey in India. 2021. (Preprint). Available: https://www.researchsquare.com/article/ rs-703258/v1

58 Meher T, Muhammad T, Gharge S. The association between single and multiple chronic conditions and depression among older population in India: a comparative study between men and women. Int J Geriatr Psychiatry 2021. doi:10.1002/gps.5639. [Epub ahead of print: 11 Oct 2021].

59 Ansari S, Muhammad T, Dhar M. How does Multi-Morbidity relate to feeling of loneliness among older adults? Evidence from a population-based survey in India. J Popul Ageing 2021;37.

60 Srivastava S, Muhammad T. Violence and associated health outcomes among older adults in India: a gendered perspective. SSM Popul Health 2020;12:100702.

61 Muhammad T, Srivastava S, Sekher TV. Association of self-perceived income sufficiency with cognitive impairment among older adults: a population-based study in India. BMC Psychiatry 2021;21:100702.

62 Muhammad T, Srivastava S. Why rotational living is bad for older adults? Evidence from a cross-sectional study in India. J Popul Ageing 2020;31.

63 Muhammad T, Balachandran A, Srivastava S. Socio-Economic and health determinants of preference for separate living among older adults: a cross-sectional study in India. PLoS One 2021;16:e0249828.

64 Mchugh ML. The chi-square test of independence lessons in biostatistics. Biochem Medica 2013.

65 Osborne J, King JE. Binary Logistic Regression. In: Best practices in quantitative methods. SAGE Publications, Inc, 2011: 358-84.

66 Chauhan S, Srivastava S, Kumar P. Interaction of substance use with physical activity and its effect on depressive symptoms among adolescents. J Subst Use 2020:1-7.

67 Muhammad T, Govindu M, Srivastava S. Relationship between chewing tobacco, smoking, consuming alcohol and cognitive impairment among older adults in India: a cross-sectional study. BMC Geriatr 2021;21:85.

68 Sahni B, Bala K, Kumar T, et al. Prevalence and determinants of geriatric depression in North India: a cross-sectional study. J Family Med Prim Care 2020;9:2332-6.

69 Sinha D, Mishra PS, Srivastava S, et al. Socio-Economic inequality in the prevalence of violence against older adults - findings from India. BMC Geriatr 2021;21:1-12.

70 Nagpaul K. Elder abuse among Asian Indians: traditional versus modern perspectives. J Elder Abuse Negl 1997;9:77-92.

71 Bordoloi A, Ali A, Islam S. Elder abuse and its association with depression and social support: a community-based study from Tezpur, Assam. J Geriatr Ment Heal 2018;5:128.

72 Gupta SK, Sekher TV. Vulnerability and Coping Mechanism of Aged: A Study of Elderly Widows in Jharkhand. In: Elderly care in India: societal and state responses. Singapore: Springer, 2017.

73 Band-Winterstein T, Eisikovits Z. "Aging out" of violence: the multiple faces of intimate violence over the life span. Qual Health Res 2009;19:164-80.

74 Stöckl H, Watts C, Penhale B. Intimate partner violence against older women in Germany: prevalence and associated factors. $J$ Interpers Violence 2012;27:2545-64.

75 Knight L, Hester M. Domestic violence and mental health in older adults. Int Rev Psychiatry 2016;28:464-74.

76 Dahal M, Dhakal S, Khanal S, et al. Linkage of depression with elder abuse among institutionalized older persons in Kathmandu Valley, Nepal. Psychiatry J 2021;2021:1-8.

77 Kilian R, Müller-Stierlin A, Lamp N, et al. Criminal victimization, cognitive social capital and mental health in an urban region in Germany: a path analysis. Soc Psychiatry Psychiatr Epidemiol 2021:56:1565-74.

78 Weisner L, Otto HD, Adams S. Issues in policing rural areas: a review of the literature, 2020.

79 Whitley R, Prince M. Fear of crime, mobility and mental health in inner-city London, UK. Soc Sci Med 2005;61:1678-88.

80 Choi YJ, Matz-Costa C. Perceived neighborhood safety, social cohesion, and psychological health of older adults. Gerontologist 2018;58:196-206.

81 Kappes C, Greve W, Hellmers S. Fear of crime in old age: precautious behaviour and its relation to situational fear. Eur $J$ Ageing 2013;10:111-25.

82 Won J, Lee C, Forjuoh SN, et al. Neighborhood safety factors associated with older adults' health-related outcomes: a systematic literature review. Soc Sci Med 2016;165:177-86.

83 Sutton RM, Gender FS. Gender, socially desirable responding and the fear of crime: are women really more anxious about crime? $\mathrm{Br} J$ Criminol 2005;45:212-24. 